\title{
Interaction between the Corticotropin-Releasing Factor System and Hypocretins (Orexins): A Novel Circuit Mediating Stress Response
}

\author{
Raphaëlle Winsky-Sommerer, ${ }^{1}$ Akihiro Yamanaka, ${ }^{3,4}$ Sabrina Diano, ${ }^{5}$ Erzsebet Borok, ${ }^{5}$ Amanda J. Roberts, ${ }^{2}$ \\ Takeshi Sakurai, ${ }^{4}$ Thomas S. Kilduff, ${ }^{3}$ Tamas L. Horvath, ${ }^{5,6}$ and Luis de Lecea ${ }^{1,2}$ \\ Departments of ${ }^{1}$ Molecular Biology and ${ }^{2}$ Neuropharmacology, The Scripps Research Institute, La Jolla, California 92037, ${ }^{3}$ Molecular Neurobiology \\ Laboratory, Stanford Research Institute International, Menlo Park, California 94025, ${ }^{4}$ Department of Pharmacology, Institute of Basic Medical Sciences, \\ University of Tsukuba, Ibaraki 305-8575, Japan, and Departments of ${ }^{5}$ Obstetrics and Gynecology and ${ }^{\circ}$ Neurobiology, Yale University School of Medicine, \\ New Haven, Connecticut 06520
}

The hypothalamic neuropeptides hypocretins (orexins) play a crucial role in the stability of arousal and alertness. We tested whether the hypocretinergic system is a critical component of the stress response activated by the corticotropin-releasing factor (CRF). Our results show that CRF-immunoreactive terminals make direct contact with hypocretin-expressing neurons in the lateral hypothalamus and that numerous hypocretinergic neurons express the CRF-R1/2 receptors. We also demonstrate that application of CRF to hypothalamic slices containing identified hypocretin neurons depolarizes membrane potential and increases firing rate in a subpopulation of hypocretinergic cells. CRF-induced depolarization was tetrodotoxin insensitive and was blocked by the peptidergic CRF-R1 antagonist astressin. Moreover, activation of hypocretinergic neurons in response to acute stress was severely impaired in CRF-R1 knock-out mice. Together, our data provide evidence of a direct neuroanatomical and physiological input from CRF peptidergic system onto hypocretin neurons. We propose that, after stressor stimuli, CRF stimulates the release of hypocretins and that this circuit contributes to activation and maintenance of arousal associated with the stress response.

Key words: hypocretin; orexin; corticotropin-releasing factor; hypothalamus; stress; homeostasis

\section{Introduction}

Hypocretin-1/orexin-A (hcrt-1) and hypocretin-2/orexin-B (hcrt-2) are two neuropeptides produced from a common precursor (de Lecea et al., 1998; Sakurai et al., 1998). They bind to two G-protein-coupled receptors, hypocretin receptor-1 (hcrtr1/ox1r) and hypocretin receptor-2 (hcrt-r2/ox2r) (Sakurai et al., 1998). The production of the hypocretin peptides is restricted to a subset of neurons located in the perifornical region of the lateral hypothalamus area (de Lecea et al., 1998). Projections of the hypocretinergic cells and expression sites of their receptors are widely distributed throughout the brain, including the hypothalamus, thalamus, and brainstem, as well as the peripheral autonomic nervous system (Peyron et al., 1998; Hervieu et al., 2001; Cluderay et al., 2002). Recent reports demonstrated their key role in the regulation of vigilance states and in the promotion of arousal. Indeed, pre-prohypocretin knock-out mice and dogs

Received March 2, 2004; revised Nov. 4, 2004; accepted Nov. 10, 2004.

This work was supported by National Institutes of Health Grants MH58543, RR014451, MH059847, DK060711, R21AA13241, and MH61755. We thank Drs. Wylie Vale and George Koob for providing the CRF-R1 knock-out mice and Marya Shanabrough for her excellent technical assistance.

Correspondence should be addressed to Dr. Luis de Lecea, Departments of Molecular Biology and Neuropharmacology, The Scripps Research Institute, MB-10, 10550 North Torrey Pines Road, La Jolla, CA 92037. E-mail: llecea@scripps.edu.

DOI:10.1523/JNEUROSCI.3459-04.2004

Copyright $\odot 2004$ Society for Neuroscience 0270-6474/04/2411439-10\$15.00/0 with null mutations in the hcrt-r2 receptor gene undergo periods of cataplexy-like attacks and sudden onsets of rapid-eye movement (REM) sleep, a phenotype remarkably similar to human narcolepsy (Chemelli et al., 1999; Lin et al., 1999; Willie et al., 2003). Mice with selective postnatal degeneration of hypocretinergic neurons display identical behavioral abnormalities (Hara et al., 2001). Moreover, analysis of hcrt-r2 knock-out mice has shown that regulation of wake-non-REM sleep transition depends on hcrt-r2 activation (Willie et al., 2003).

Several lines of evidence support a role of the hypocretins as modulators of the stress response. Hypocretins promote arousal and alertness by suppressing REM sleep and lowering the arousal threshold (Sutcliffe and de Lecea, 2002). Hypocretins also stimulate energy expenditure (Yoshimichi et al., 2001), as well as sympathetic nervous system activity (Samson et al., 1999; Shirasaka et al., 1999; Chen et al., 2000; Samson et al., 2002). Indeed, intracerebroventricular administration of hcrt-1 increases feeding behavior, locomotor activity (Hagan et al., 1999; Samson et al., 1999), and body temperature (Yoshimichi et al., 2001). In addition, hypocretin-1 also stimulates gastric secretion in a dose-dependent manner (Takahashi et al., 1999) and increases arterial blood pressure, heart rate (Samson et al., 1999), cerebral blood flow, and renal sympathetic nerve activity (Shirasaka et al., 1999).

During stress, activation of the hypothalamic-pituitary- 
adrenal (HPA) axis is initiated by corticotropin-releasing factor (CRF), which is synthesized in the paraventricular hypothalamic nucleus (PVN). Stimulation of the pituitary corticotroph cells by $\mathrm{CRF}$ results in the production of adrenocorticotropic hormone (ACTH), which elicits the release of glucocorticoids from the adrenal gland (Owens and Nemeroff, 1991). Two G-coupled CRF receptors subtypes (CRF-R1 and CRF-R2) have been isolated. CRF-R1 receptors play a major role in mediating the HPA axis response to stress (Smith et al., 1998; Timpl et al., 1998).

Here we evaluate the involvement of the hypocretinergic system in the stress response activated by CRF. We first describe anatomical interactions between CRF and hypocretinergic systems. We demonstrate ex vivo that CRF increases membrane potential and firing rate of hypocretinergic neurons. We also provide evidence that the stress-induced activation of hypocretinergic neurons occurs through CRF-R1 receptors. Our findings have direct physiological implications in arousal associated with the stress response.

\section{Materials and Methods}

Animals and challenge procedures

For acute challenge procedures, CRF-R1 knock-out mice and wild-type littermate controls (20-35 gm) on a B6 $\times 129$ background (provided by Dr. Wylie Vale, Salk Institute, La Jolla, CA) were used. Mice were tested during the dark (active) portion of their circadian cycle ( $12 \mathrm{hr}$ light/dark cycle; lights on at 7:00 P.M. and off at 7:00 A.M.; ad libitum access to food and water). All procedures were approved by the Institutional Animal Care and Use Committee of the Scripps Research Institute. All challenge procedures began at 9:30 A.M.

For acute restraint stress, mice were placed in $50 \mathrm{ml}$ conical tubes that had an opening to allow air flow for $30 \mathrm{~min}$. Restraint stress has been shown to induce an increase in CRF mRNA levels in both the PVN and the central nucleus of the amygdala (for review, see Makino et al., 2002). For footshock stress, mice were individually placed in a soundattenuating chamber installed with a shockable grid floor. They were then exposed to two mild footshocks of $0.70 \mathrm{~mA}, 2 \mathrm{sec}$ in duration in a 5.5 min session. Intermittent electrical footshock has been shown to induce c-Fos expression in parvocellular PVN neurons expressing CRF, as well as biosynthetic and secretory activity at each level of the HPA axis (for review, see Makino et al., 2002).

After either challenge, mice were released back into their individual cages and were killed $1 \mathrm{hr}$ after the challenge procedure. Deeply anesthetized animals (using $5 \%$ halothane) were transcardially perfused with ice-cold $4 \%$ paraformaldehyde in $0.1 \mathrm{~m}$ phosphate buffer, $\mathrm{pH} 7.4(\mathrm{~PB})$. Brains were removed and cryoprotected in $30 \%$ sucrose solution. Brains were then frozen, and $25-\mu \mathrm{m}$-thick sections were collected in cryoprotectant solution (30\% glycerol and 30\% ethylene glycol in $0.1 \mathrm{M} \mathrm{PBS}$ ).

\section{Immunohistochemical procedures}

Antisera. A polyclonal hypocretin antiserum was raised in rabbit by immunization with the bacterially expressed histidine-tagged preprohypocretin (residues 28-130-amide; antiserum 2123); biochemical and immunohistochemical characterization of the antibody have been reported previously (de Lecea et al., 1998; Peyron et al., 1998). To detect hypocretin immunoreactivity, we also used a goat polyclonal antibody (Santa Cruz Biotechnology, Santa Cruz, CA). A rabbit polyclonal antibody raised against CRF was used (Peninsula Laboratories, San Carlos, $\mathrm{CA})$. We also used a goat polyclonal anti-CRF-R1/2 receptor antiserum (Santa Cruz Biotechnology) and rabbit polyclonal serum directed against c-Fos (Oncogene Research Products, San Diego, CA).

Light and electron microscopic double immunostaining for hypocretins versus $C R F$. Light microscopic double immunostaining for hypothalamic CRF and hypocretins was performed according to the following protocol. Sections were immunostained for CRF (rabbit anti-CRF, 1:1000; Peninsula Laboratories) for $24 \mathrm{hr}$ at room temperature (r.t.). Sections were then incubated in biotinylated anti-rabbit IgG at 1:250 in phosphate buffer (Vector Laboratories, Burlingame, CA), followed by avidin-biotin-peroxidase complex (ABC) (1:50 in PB; ABC Elite Kit; Vector Laboratories), both for $2 \mathrm{hr}$ at r.t. The tissue-bound peroxidase was visual-

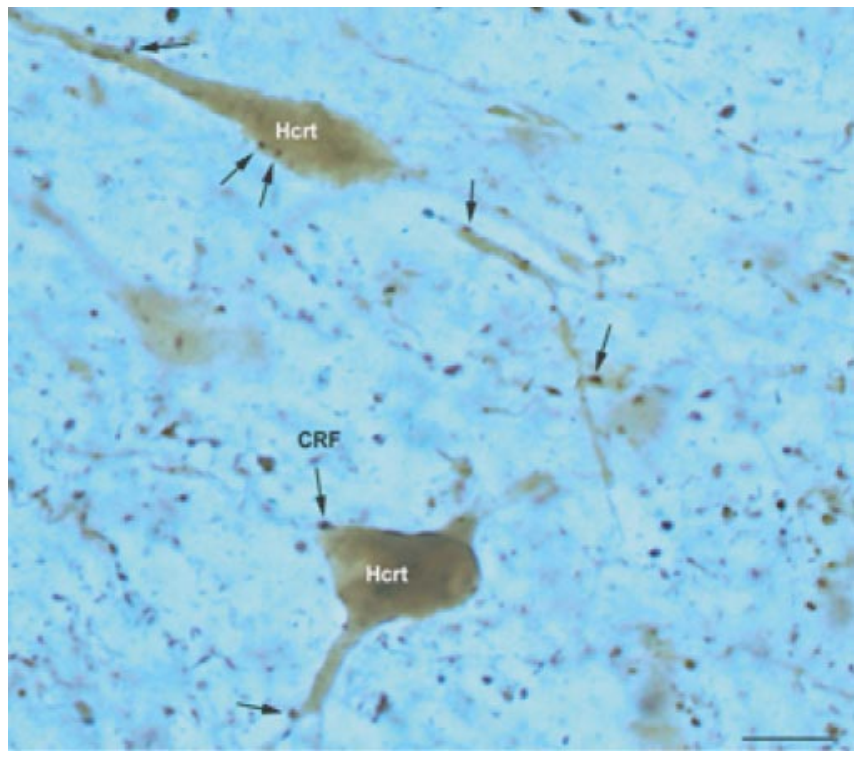

Figure 1. Putative contacts between CRF bouton-like structures and hypocretinergic neurons in the lateral hypothalamus. CRF-immunoreactive boutons (arrow; DAB-nickel) were observed in close apposition to hypocretin-expressing perikarya and dendrites (DAB). Scale bar, $10 \mu \mathrm{m}$.

ized by a modified version of the diaminobenzidine-nickel (DAB-Ni) reaction (15 mg of $\mathrm{DAB}, 0.12 \mathrm{mg}$ of glucose oxidase, $12 \mathrm{mg}$ of ammonium chloride, $600 \mu \mathrm{l}$ of $0.05 \mathrm{~m}$ nickel ammonium sulfate, and $600 \mu \mathrm{l}$ of $10 \% \beta$-D-glucose in $30 \mathrm{ml}$ of $\mathrm{PB}$ ) for $10-30 \mathrm{~min}$ at r.t., resulting in a dark blue reaction product. After several rinses in $\mathrm{PB}$, the sections were further incubated in goat anti-hypocretin (1:500; Santa Cruz Biotechnology) antiserum for $24 \mathrm{hr}$ at $4^{\circ} \mathrm{C}$, followed by secondary antibody (anti-goat IgG diluted 1:50 in $\mathrm{PB}$ ) and goat peroxidase-anti-peroxidase (1:100 in $\mathrm{PB})$, both steps for $2 \mathrm{hr}$ at r.t. Between each incubation step, the sections were rinsed (four times for $10 \mathrm{~min}$ each) in PB. The tissue-bound peroxidase was visualized by a DAB reaction (15 mg of DAB and $165 \mu \mathrm{l}$ of $0.3 \%$ $\mathrm{H}_{2} \mathrm{O}_{2}$ in $30 \mathrm{ml}$ of $\mathrm{PB}$ ), resulting in a light brown reaction product. The colors of the two reaction products were easily distinguishable, and, in single-stained material in which one of the primaries was omitted, only one color was found. After immunostaining, the sections were thoroughly rinsed in $\mathrm{PB}$ and processed for correlated electron microscopy. Sections were wet mounted in $\mathrm{PB}$ and examined under the light microscope. Color photographs and images were taken of CRF-immunoreactive boutons making putative contact on hcrt-immunoreactive cells. Sections were then osmicated $\left(1 \% \mathrm{OsO}_{4}\right.$ in $\left.\mathrm{PB}\right)$ for $30 \mathrm{~min}$, dehydrated through increasing ethanol concentrations (using 1\% uranyl acetate in the 70\% ethanol for 30 min), and flat embedded in Araldite between liquid release-coated slides and coverslips (Electron Microscopy Sciences, Fort Washington, PA). Blocks were trimmed using the color picture of previously identified cells and boutons as a guide. Ribbons of serial ultrathin sections were collected on Formvar-coated single slot grids and examined under the electron microscope.

Light microscopic double immunostaining for hypocretins and CRF-R1/2 or c-Fos. Free-floating sections were rinsed in $0.1 \mathrm{M}$ PBS, pH 7.4, and then treated 30 min in $\mathrm{H}_{2} \mathrm{O}_{2}(0.3 \%)-\mathrm{PBS}$ solution. Sections were then incubated overnight at $4^{\circ} \mathrm{C}$ in blocking solution $(4 \%$ BSA-0.1\% Triton $\mathrm{X}-100-\mathrm{PBS}$ ) containing different combinations of antisera: (1) rabbit polyclonal antiserum directed against hypocretin-1 (diluted 1:1500 and developed with DAB) with goat polyclonal anti CRF-R1/2 (1:1000) receptor (developed with $\mathrm{DAB}-\mathrm{NiCl}_{2}$ ); and (2) goat polyclonal antibody directed against hypocretin-1 (developed with $\mathrm{DAB}$ ) and rabbit polyclonal antibody against c-Fos (developed with $\mathrm{DAB}-\mathrm{NiCl}_{2}$ ) diluted 1:1500 and 1:12,000 respectively. As specificity control, CRF-R1/2 antiserum was preadsorbed with its appropriate antigenic peptide $(2 \mu \mathrm{g} / \mathrm{ml}$; Santa Cruz Biotechnology). Then, sections were processed sequentially to develop first the immunoreactivity detected with $\mathrm{DAB}-\mathrm{NiCl}_{2}$ by incubating the sections for $45 \mathrm{~min}$ at r.t. in blocking solution containing a 

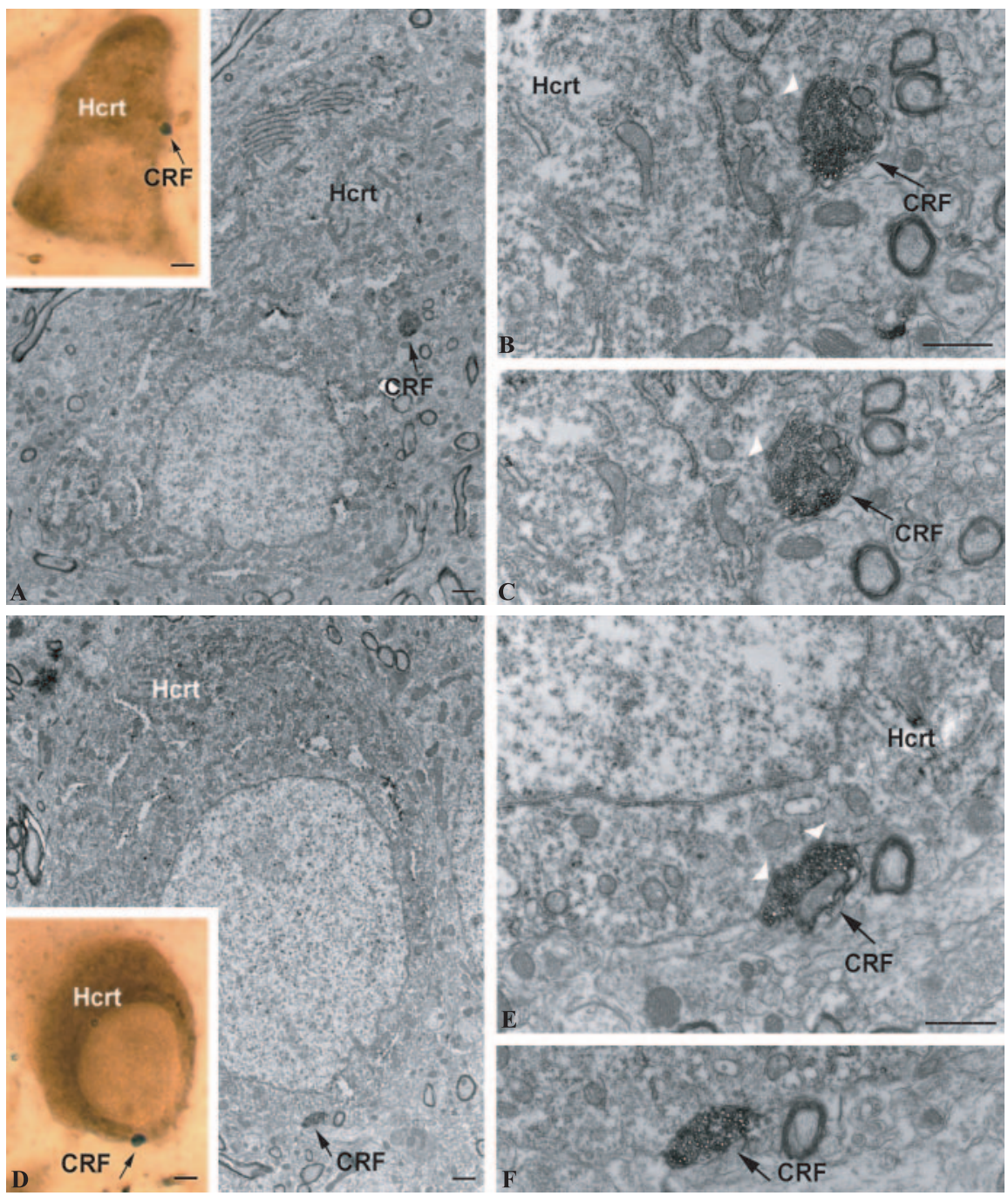

Figure 2. Synaptic interaction between $C R F$ axons and hypocretin. $A-C, D-F$, Correlated light and electron micrographs demonstrating black-labeled CRF axon terminals (black arrow) synapsing on hypocretin-immunoreactive perikarya. $A$ and $D$ are the light micrographs of the putative contacts. Scale bar (in $A, D), 2 \mu \mathrm{m} . B, C, E, F$, Electron micrograph showing an asymmetrical synaptic membrane specialization (white arrowheads) between the same CRF bouton-like structure $(A, D)$ and the hypocretinimmunolabeled perikaryon in the lateral hypothalamus. Scale bars: $B, E, 1 \mu \mathrm{m}$.

biotinylated donkey anti-rabbit IgG (1:500; Jackson ImmunoResearch, West Grove, PA) or a biotinylated donkey anti-goat (1:500) IgG. Sections were then processed in an $\mathrm{ABC}$ solution (Vector Laboratories) for another $45 \mathrm{~min}$. Sections were rinsed three times in PBS, and the immunoreactivity could be visualized as a black reaction product after $7 \mathrm{~min}$ detection in a $0.04 \%$ DAB solution containing $0.01 \% \mathrm{H}_{2} \mathrm{O}_{2}$ with $0.4 \%$ nickel-chloride. Brain sections were further incubated with either a biotinylated donkey polyclonal anti-goat or the biotinylated donkey polyclonal anti-rabbit for $45 \mathrm{~min}$ and processed in the $\mathrm{ABC}$ solution for an additional $45 \mathrm{~min}$. The immunoreactivity was visualized as a brown reaction product after 9 min detection in a $0.04 \%$ DAB solution containing $0.01 \% \mathrm{H}_{2} \mathrm{O}_{2}$. Sections were analyzed using standard light microscopy with a Zeiss (Oberkochen, Germany) Axioplan microscope.

For immunofluorescence, sections were coincubated overnight in blocking solution containing CRF-R1/2 (1:1500) and hypocretin (1:1000) antibodies. Sections were then processed to develop CRF-R1/2 immunoreactivity by sequential incubations with a biotinylated donkey anti-goat IgG (Jackson ImmunoResearch) and then in ABC solution (Vector Laboratories). They were subsequently incubated in 1:100 fluorescein tyramide solution (TSA-direct; PerkinElmer Life Sciences, Boston, MA). For hypocretin immunoreactivity, sections were further incubated for $45 \mathrm{~min}$ in Alexa Fluor 594-conjugated goat anti-rabbit IgG (Molecular Probes, Eugene, OR).
Evaluation of the colocalization of CRF-R1/2 and hypocretin immunoreactivities. The number of hypocretin-immunoreactive neurons displaying a concomitant CRF-R1/2 labeling were counted bilaterally in consecutive sections in a minimum of four different sections $(n=508$ hypocretinergic neurons) from three wild-type mice at the level of the perifornical area of the dorsolateral hypothalamus based on the atlas of Franklin and Paxinos (1997). Data were expressed as mean \pm SEM (GraphPad Prism 4.0; GraphPad Software, San Diego, CA).

Evaluation of the colocalization of $c$-Fos and hypocretin immunoreactivities. The number of hypocretin-immunoreactive neurons displaying a concomitant c-Fos immunoreactive nucleus were counted bilaterally in consecutive sections in a minimum of six different sections from three animals at the level of the perifornical area of the dorsolateral hypothalamus based on the atlas of Franklin and Paxinos (1997). Data were expressed as mean \pm SEM. The effect of stress was analyzed by one-way ANOVA $(p<0.001)$ using the GraphPad Prism 4.0 software.

\section{Electrophysiological recordings}

Hypothalamic slice preparation and recording conditions followed the procedures described by Yamanaka et al. (2003). Briefly, male and female mice (3-6 weeks of age) in which the hypocretin promoter was linked to enhanced green fluorescent protein (orexin/EGFP mice) were used for the experiments (Yamanaka et al., 2003b). Mice were deeply anesthetized with methoxyflurane and then decapitated. Brains were isolated in ice-cold physiological solution bubbled with $95 \% \mathrm{O}_{2}-5 \% \mathrm{CO}_{2}$ containing the following (in mM): $135 \mathrm{NaCl}, 5 \mathrm{KCl}, 1 \mathrm{CaCl}_{2}, 1$ $\mathrm{MgCl}_{2}, 25 \mathrm{NaHCO}_{3}$, and 10 glucose. Brains were cut coronally into $250 \mu \mathrm{m}$ slices with a microtome (VT1000S; Leica, Nussloch, Germany). Slices containing the lateral hypothalamic area were transferred to an incubation chamber, where they were superfused with physiological solution at a rate of $3 \mathrm{ml} / \mathrm{min}$ by gravity flow and remained at room temperature $\left(24-26^{\circ} \mathrm{C}\right)$ for at least $1 \mathrm{hr}$ before recording. Orexin/EGFP neurons were visualized on an upright microscope (DM LFSA; Leica) using both infrared and differential interference contrast (IR-DIC) microscopy and fluorescence microscopy. Infrared images were acquired via chargecoupled device camera optimized for infrared wavelengths (Dage-MTI, Michigan City, IN); fluorescent images were acquired using a fluorescent camera and digitizer system (LEI-750D; Leica). Images were displayed on separate monitors [PVM137 (Sony, Tokyo, Japan) black and white video monitor for IR-DIC and PVM1342Q (Sony) Trinitron color video monitor for fluorescence] and were saved on a computer.

Patch pipettes were prepared from borosilicate glass capillaries (GC150-10; Harvard Apparatus, Holliston, MA) with a micropipette puller (P-97; Sutter Instruments, Novato, CA). The pipettes were filled with an internal solution containing the following (in $\mathrm{mM}$ ): $145 \mathrm{KCl}, 1$ $\mathrm{MgCl}_{2}, 1.1$ EGTA- $\mathrm{Na}_{3}, 10$ HEPES, $2 \mathrm{Na}_{2} \mathrm{ATP}$, and $0.5 \mathrm{Na}_{2} \mathrm{GTP}$, pH 7.2 with $\mathrm{KOH}$. Osmolarity of solution was checked by an osmometer (Advanced Instruments, Norwood, MA). Pipette resistance was 4-10 M $\Omega$. The series resistance during recording was $10-25 \mathrm{M} \Omega$. Recording pipettes were advanced toward individual fluorescent cells in a slice while under positive pressure, and, on contact, tight seals on the order of $0.5-$ $1.0 \mathrm{G} \Omega$ were made by negative pressure. The membrane patch was then ruptured by suction and membrane potential was monitored using an 
Axopatch 1D patch-clamp amplifier (Axon Instruments, Foster City, CA). The following pharmacological agents were used: CRF (Bachem, Torrance, CA); tetrodotoxin (TTX) (Wako Pure Chemical Industries, Ltd., Osaka, Japan); the peptidergic CRF-R1 antagonist astressin (Sigma, St Louis, MO); and the CRF-R2 receptor-selective agonist stresscopin (Peptide Institute, Osaka, Japan).

Statistics. The magnitude of depolarization of orexin/EGFP neurons evoked by CRF application was analyzed by ANOVA using Statview 5.0.1 (SAS Institute, Cary, NC). When ANOVA indicated significance among groups, Fisher's protected least significant difference test was used to determine which groups differed from each other.

\section{Results}

Anatomical interactions between the CRF and hypocretin peptidergic systems The overall patterns of hypocretin and CRF immunolabelings in the mouse CNS are consistent with those described previously (Merchenthaler et al., 1982; de Lecea et al., 1998; Sakurai et al., 1998). Few CRFimmunoreactive neurons were detected in the parvocellular part of the PVN, as well as in the central nucleus of the amygdala and cortex. Hypocretin-immunopositive perikarya were seen in the lateral hypothalamus-perifornical area. A dense network of hypocretin-containing fibers was present in regions containing CRF-expressing perikarya, i.e., PVN and central nucleus of the amygdala. CRF-immunoreactive fibers were abundant in the lateral hypothalamus (Fig. 1).

\section{CRF axons contact}

hypocretin-immunopositive cells

Figure 1 shows close appositions of CRFimmunoreactive bouton-like structures contacting hypocretin-immunopositive perikarya in the lateral hypothalamus. Frequently, CRF fibers were detected in close proximity to hypocretin-containing proximal and distal dendrites (Fig. 1).

Putative contacts between an identified single CRF-immunopositive bouton-like structure with a hypocretin-immunopositive perikaryon were further investigated by electron microscopy (Fig. 2). Ultra-

structural analysis confirmed the occurrence of synapses between these CRF-immunoreactive boutons and hypocretinergic neurons (Figs. $2 D-F, 3)$. Analyzed synapses $(n=10)$ between CRFimmunoreactive axons and postsynaptic hypocretinergic neurons were exclusively asymmetrical, Gray type I synaptic membrane specializations. CRF axon terminals contained large dense-core vesicles (Fig. 3) and small clear vesicles that probably contain a fast-acting transmitter (Figs. 2, 3). Synaptic membrane specialization was determined by serial sectioning of each of the 10 CRF-immunopositive boutons. An example of such serial sectioning is seen on Figure 3. CRF-immunoreactive boutons that established asymmetrical contacts were also in close proximity to

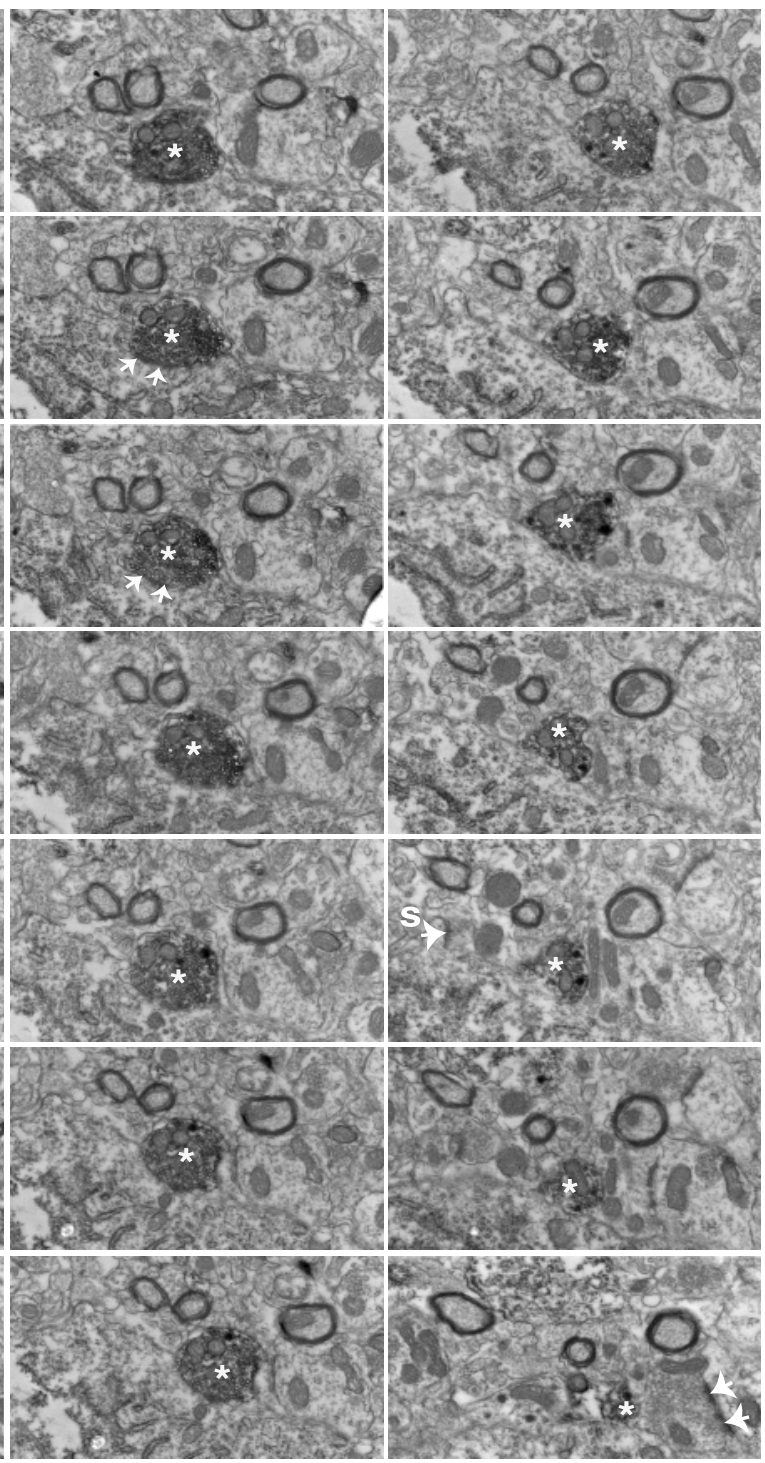

Figure 3. Serial sections of a CRF axon terminal on hcrt perikaryon. Electron micrographic panels (from left to right, top to bottom in sequence) showing the emergence and dissipation of a (RF-immunoreactive bouton (white asterisk) in association with orientation of the panels in this figure is $90^{\circ}$ counterclockwise rotated compared with their position on Figure 2. The CRFimmunoreactive bouton establishes an asymmetrical contact with the hort perikarya (white arrows). The same bouton is also in vesicles immunolabeled for CRF appear in the vicinity of this unlabeled presynaptic terminal. This ultrastructural substrate is consistent with the observed effect of TTX on CRF-induced depolarization of hert neurons, suggesting both direct postsynaptic and presynaptic effects of CRF. Another interesting feature of hypocretinergic perikarya was the presence of somatic spines, which received asymmetrical contacts (white arrow). Scale bar, $1 \mu \mathrm{m}$.

other presynaptic terminals, which themselves were also predominantly found in asymmetrical contacts with the same hypocretin-labeled perikarya (Fig. 3). Another interesting feature of hypocretinergic perikarya was the presence of somatic spines (Fig. 3), which received asymmetrical contacts as well.

\section{$C R F-R 1 / 2$ receptor immunoreactivity in hypocretinergic} cell bodies

Immunostaining for CRF-R1/2 receptors showed the same regional and cellular distribution reported previously in the murine brain, using the same antiserum (Chen et al., 2000; Sauvage and Steckler, 2001). In these experiments, specificity was demonstrated by the complete inhibition of staining after preadsorption 

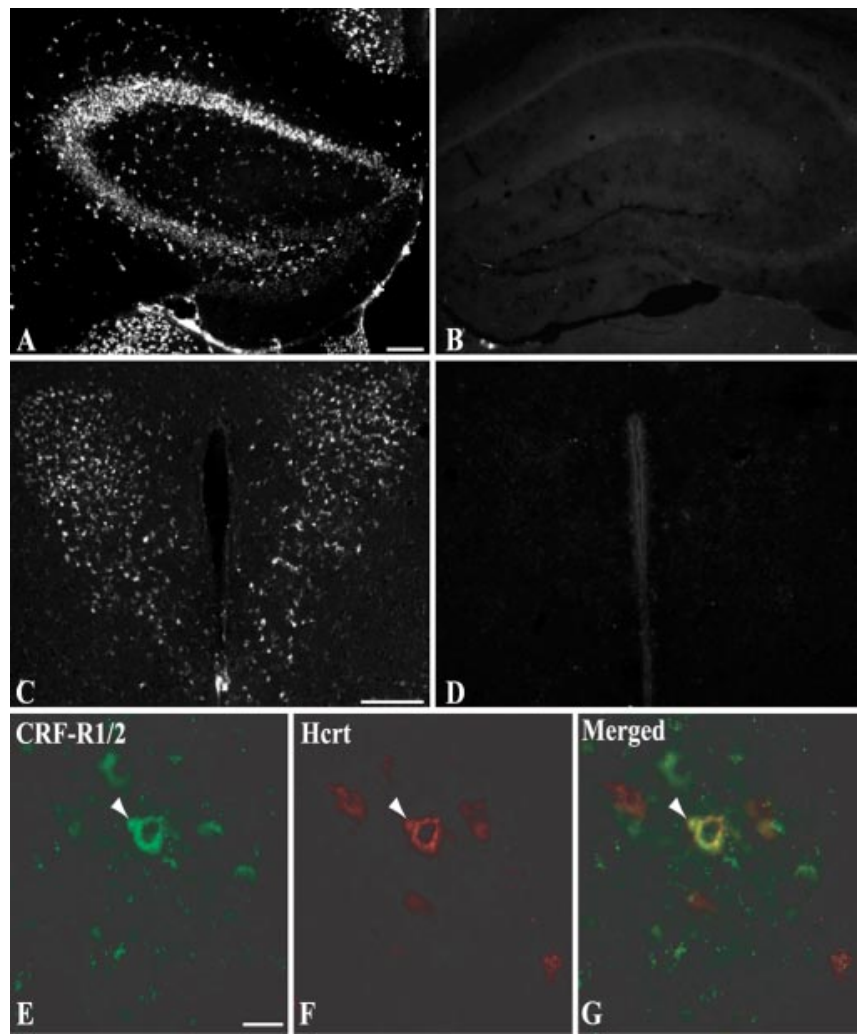

Figure 4. Specificity controls of CRF-R1/2 immunostaining in the brain. Sections at the leve of the hippocampus $(A)$ and paraventricular nucleus of the hypothalamus $(C)$ display positive immunofluorescent staining with CRF-R1/2 antibody. Immunoreactive signals are no longer apparent when the antiserum was preadsorbed with the immunogenic peptide $(B, D)$. Scale bars: $A, B, 200 \mu \mathrm{m} ; C, D, 80 \mu \mathrm{m}$; (in $E) E-G, 10 \mu \mathrm{m}$. $E-G$, Double labeling of tissue sections at the level of the lateral hypothalamus, respectively, showing the CRF-R1/2 $(E)$ and the hypocretin $(F)$ immunoreactivities. $F$, Merged image of $E$ and $F$, illustrating the colocalization (yellow signal, arrow) between (RF-R1/2 (green) and hypocretin (red).

of the antiserum with the immunogenic epitope (Fig. $4 B, D$ ). At high magnification, immunoreactivity for CRF receptors displayed either punctate or homogenous patterns (Fig. $4 E$ ). Numerous labeled neurons for CRF-R1 were found to be distributed in the lateral hypothalamic area (Fig. 5A). Analysis of double-labeled sections showed that a large proportion of hypocretin-immunoreactive neurons were expressing CRF receptors $(63.95 \pm 2.28 \%$ hypocretinergic/CRF-R1/2-positive neurons $(n=508)$ (Figs. $4 E-G, 5)$.

\section{Electrophysiological effects of CRF on hypocretinergic neurons}

We assessed the effects of CRF on hypocretin-producing cells ex vivo using hypothalamic slices from transgenic mice expressing enhanced green fluorescent protein selectively in hypocretin neurons (Yamanaka et al., 2003b). A total of 32 orexin/EGFP neurons were tested for sensitivity to CRF; eight of these cells responded to CRF application (Fig. 6A). In most experiments, CRF was applied for $2 \mathrm{~min}$, and, after an initial delay, a substantial depolarization and robust increase in firing rate were observed that lasted as long as CRF was in the bathing medium; the response was always reversible after washout. Some hypocretinergic cells were silent before CRF application but became active after CRF was applied. ANOVA revealed that the response to CRF was dose dependent in four cells that were tested with multiple concentrations of CRF $\left(p=0.0002 ; F_{(2,9)}=24.392\right)$ (Fig. $\left.6 B\right)$. A delay in

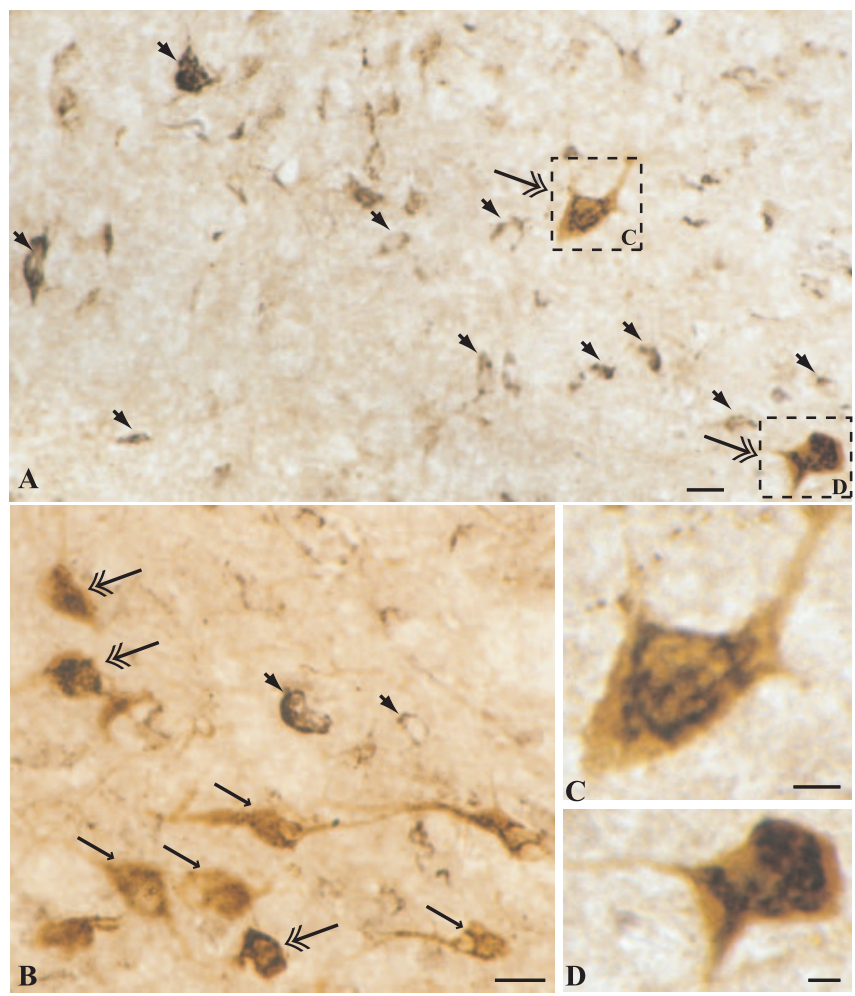

Figure 5. Hypocretin-producing cells express CRF receptors. $A, B$, Neurons in the perifornical region of the lateral hypothalamus express CRF receptors (large solid arrow; black reaction product). Double labeling shows that numerous hypocretin-immunopositive perikarya displayed (RF-R1/2 immunoreactivity (double arrow). Single-labeled hypocretin-expressing neurons are shown by arrow (brown reaction product). Scale bars: $A, B, 10 \mu \mathrm{m} . C, D$, Higher magnification of two hypocretinergic neurons (frames in $A$ ) illustrating colocalization of hypocretin and CRF-R1 immunoreactivities. Scale bars: $C, D, 2.5 \mu \mathrm{m}$.

the onset of the response of the hypocretin neurons to CRF application was observed, and membrane resistance decreased by $80 \%$ after application of $300 \mathrm{~nm}$ CRF. Although these results are consistent with opening of an ion channel, the possibility of closing of a $\mathrm{K}^{+}$channel or a combination of both of these mechanisms cannot be excluded. Additional detailed experiments are needed to elucidate the specific channel(s) involved.

As indicated in Figure $6 B$, post hoc tests revealed a significant difference in firing rate with the concentrations tested: those neurons that were active before CRF treatment underwent a $200 \pm$ $28.9 \%$ increase in firing rate when $100 \mathrm{~nm}$ CRF was applied. TTX application $(1 \mu \mathrm{M})$ attenuated but did not block CRF-induced depolarization $(n=4 ; 5.1 \pm 0.32$ vs $9.8 \pm 1.8 \mathrm{mV} ; p=0.13)$, suggesting both presynaptic and postsynaptic effects.

To determine whether the depolarizing effects of CRF were mediated by CRF-R1 or CRF-R2, we pretreated hypothalamic slices with the peptidergic CRF-R1 antagonist astressin $(1 \mu \mathrm{M})$. As indicated in Figure 6, $C$ and $D, C R F-i n d u c e d$ depolarization was inhibited by pretreatment with astressin $(n=4 ; 5.1 \pm 0.32$ vs $0.1 \pm 0.12$ $\mathrm{mV} ; p=0.0003)$. On the other hand, the CRF-R2 selective agonist stresscopin (300 nM) did not affect the membrane potential of 20 randomly selected hypocretin neurons (data not shown).

\section{Decreased activation of hypocretinergic neurons during stress in CRF-R1 knock-out mice}

c-Fos can be used as a marker for functional activation to monitor stress-related neuroendocrine circuitries (Chan et al., 1993). c-Fos immunoreactivity was monitored $1 \mathrm{hr}$ after acute stress 
challenges, i.e., footshocks and restraint stress, to determine whether hypocretinexpressing neurons were sensitive to stress in these two acute stress paradigms. Paraventricular responsiveness was confirmed after restraint stress and footshocks. As expected, we observed a strong c-Fos immunostaining in the parvocellular division of the PVN of wild-type mice subjected to both acute challenges, whereas only few scattered cells displayed nuclear labeling in control animals (data not shown).

Analysis of double-labeled cells demonstrated that hypocretinergic neurons are activated during stress in both challenge procedures (Fig. $7 A, C, E$ ). Cell counting in the perifornical region of the lateral hypothalamic area showed that the number of hypocretinergic neurons expressing c-Fos immunoreactivity was significantly increased after footshocks or restraint stress in wild-type mice (respectively, $49.09 \pm 3.22$ and $47.03 \pm$ $1.71 \%$ hypocretinergic/c-Fos-positive neurons vs $16.96 \pm 1.84 \%$ in control animals; $p<0.001$ ) (Fig. 7G).

Hypocretinergic neurons in CRF-R1 knock-out mice showed an increase of c-Fos expression after footshocks but no activation during restraint stress compared with nonstressed animals (Fig. $7 B, D, F, G)$. CRFR1-deficient animals show no differences in the number of hypocretin-immunopositive cells compared with control mice in control or stressed conditions (average, $556.5 \pm$ 69.12 cells in control vs $584.3 \pm 90.78$ hcrt neurons in CRFR1 knock-out mice; $\left.F_{(2,3)}=1.24 ; p>0.05\right)$. The number of hypocretinergic neurons expressing c-Fos was dramatically reduced in the CRF-R1 knock-out mice in both footshocks challenge (CRF-R1 knock-out mice, $25.41 \pm 1.82 \%$ hypocretinergic/c-Fospositive neurons vs $49.09 \pm 3.22 \%$ in wild-type animals; $p=$ 0.0029 ) and restraint stress [CRF-R1 knock-out mice, $11.95 \pm$ $0.84 \%$ hypocretinergic/c-Fos-positive neurons vs $47.03 \pm 1.7 \%$ in wild-type animals $\left(F_{(5,175)}=101.2 ; p<0.0001\right)$ (Fig. $\left.\left.7 G\right)\right]$. These results suggest that CRF-R1 signaling is important for the activation of hypocretinergic neurons by stress.

\section{Discussion}

The present study demonstrates that the CRF peptidergic system provides an anatomical input to hypocretin-expressing neurons and can modulate the activity of hypocretinergic neurons, as shown by electrophysiology and in the context of acute stress response.

Double light and electron microscopy analysis showed that CRF boutons establish synaptic contact with hypocretin-expressing neurons in the lateral hypothalamus (Figs. 1-3). In addition, we demonstrated that numerous hypocretin-producing neurons express CRF receptors (Figs. 4, 5). These findings provide an anatomical basis for potential modulation of hypocretinergic neurons by CRF. Interestingly, CRF boutons made asymmetrical synapses typical of excitatory axons and were associated with other presynaptic axon terminals on hypocretin neurons. This pairing of axon terminals has been reported previously (Horvath et al., 1999a; Cowley et al., 2003). These anatomical observations, along with the excitatory effect of CRF on hypocretinergic neurons (Fig. 6), suggest that CRF might enhance glutamate release from these terminals onto hypocretin neurons and thereby potentiates the depolarization of hypocretinergic neurons (Li et al., 2002; Yamanaka et al., 2003b). This idea is consistent with the observation that glutamatergic axons make apparent contact with hypocretin-expressing perikarya and primary dendrites (Li et al., 2002). However, a direct postsynaptic action of CRF on the hypocretin neurons may also occur.

We showed that the activity of hypocretin neurons is directly and dose dependently stimulated by CRF. A delay in the onset of the response of the hypocretin neurons to CRF application was observed, and membrane resistance decreased by $80 \%$ after application of $300 \mathrm{~nm}$ CRF, suggesting opening of an ion channel. CRF-induced depolarization was also observed in the presence of TTX. Although these results suggest that CRF may have a direct effect on hypocretin neurons, the data are not conclusive because TTX does not block presynaptic transmission, which depends on calcium influx through calcium channels. Additional experiments are required to elucidate the specific channel(s) involved and the indirect mechanisms of CRF-induced hort depolarization. Our experiments with CRF-R1 and CRF-R2 antagonists strongly suggest that CRF directly excites hypocretinergic neurons through CRF-R1 receptors.

We further investigated whether the interaction between CRF and hypocretin systems was relevant in the stress response. Our results show that both restraint and footshocks stress activate c-Fos in hypocretin-producing neurons (Fig. 7). These results are consistent with the observation that high-arousal states, including stress, are associated with elevated hypocretin neurotransmission (Espana et al., 2003) and that acute stress increases levels of hypocretin mRNA (Reyes et al., 2003). A metabolic challenge (i.e., fasting) induces a robust activation of both hypocretinergic neurons and the postsynaptic targets of hypocretinergic axons (Diano et al., 2003), although this effect may also be attributed to stress. Our results are consistent with the concept that distinct subsets of hypocretinergic neurons are activated during different modes of stimulation (Alam et al., 2002; Fadel et al., 2002), be- 


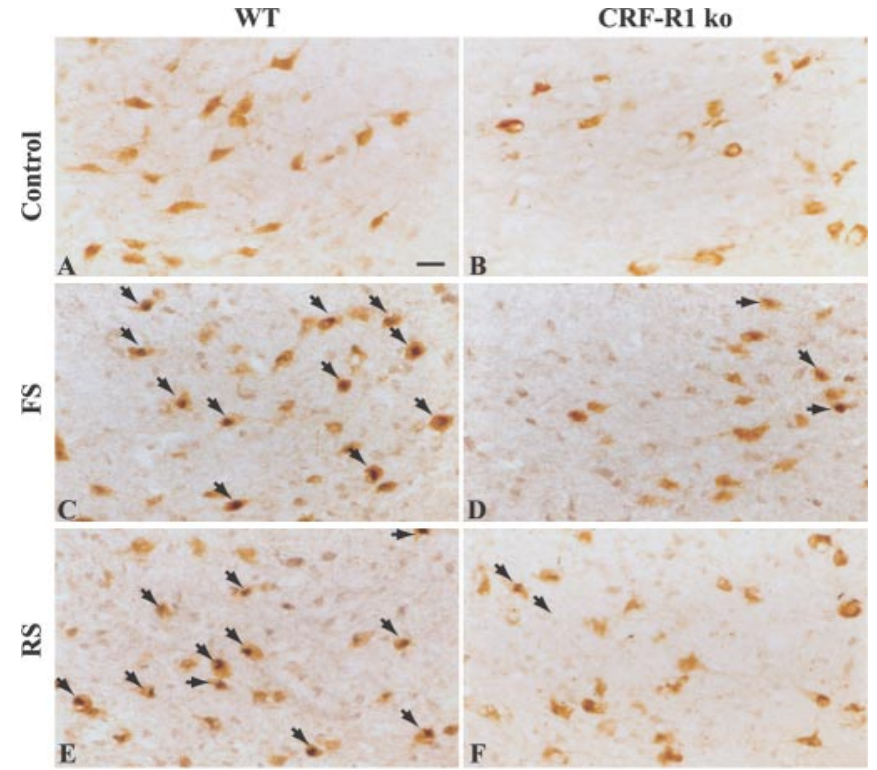

G

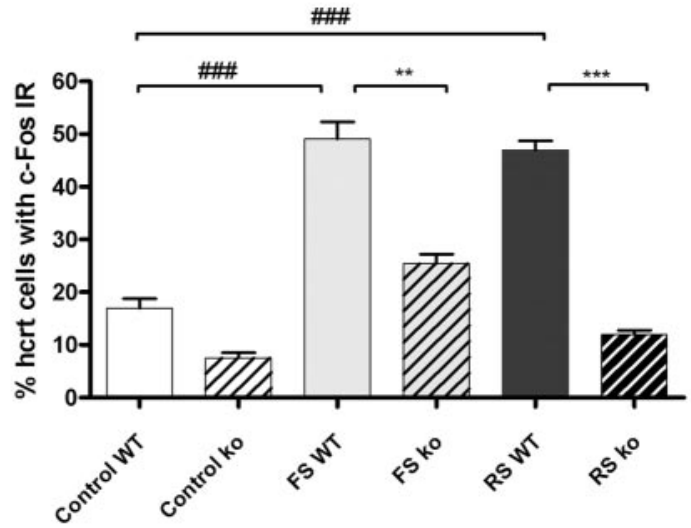

Figure 7. Activation of hypocretin neurons during footshock and restraint stress in CRF receptor 1 knock-out versus control animals. $A-F$, Representative tissue sections at the level of the perifornical area of the dorsolateral hypothalamus illustrating hypocretin (brown DAB staining) and $\mathrm{C}-\mathrm{Fos}$ (dark blue DAB-NiCl ) immunoreactivities for control groups $(A, B)$ and stressed groups ( $(-F$ ). Double-labeled neurons are shown by arrows. Scale bar (in $A), A-F, 10 \mu \mathrm{m}$. $E$, Percentage of hypocretinergic neurons immunoreactive for c-Fos in CRF-R1 knock-out (ko) versus wild-type (WT) mice during footshock (FS) or restraint stress (RS) challenge. Data are expressed as mean \pm SEM. ${ }^{* *} p<0.001$; ${ }^{* * * \# \# \# ~} p<0.0001$. n.S., Not significant.

cause only $50 \%$ of the hypocretin-expressing neurons were activated during acute stress (Fig. 7).

Our results suggest that the hypocretinergic system is a component of the circuitries contributing to CRF-mediated behaviors that occur in response to stressful situations. Indeed, the behaviors observed after hypocretin injection are similar to those observed during stress (Ida et al., 2000a), although they are less anxiogenic that the ones observed after CRF administration (Hagan et al., 1999). The hypocretins induce an intense grooming response accompanying the increase in arousal and locomotor activity (Hagan et al., 1999; Samson et al., 1999; Nakamura et al., 2000; Jones et al., 2001). These behavioral effects of hypocretins are blocked by an hcrt-r1 antagonist (Duxon et al., 2001). Interestingly, hypocretin-deficient mice display diminished behavioral response to emotional stress, suggesting that hypocretinproducing neurons play a role in one of the efferent pathways of defense response (Kayaba et al., 2003). Together, these results lead us to hypothesize that the hypocretins mediate some effects of CRF in stress. Consistent with this hypothesis are our results showing reduced activation of hcrt neurons during stress in CRF-R1 knock-out mice. Even considering the technical limitations of c-Fos immunostaining (monosynaptic vs polysynaptic activation and lack of input specificity), our data support the idea that CRF-R1 signaling in hypocretinergic neurons is an important component of the activation of the HPA axis that is impaired in CRF-R1 knock-out mice (Smith et al., 1998).

Behavioral arousal is a key component of the anxiogenic response, and CRF has been shown to increase wakefulness with a concomitant suppression of slow-wave sleep (Ehlers et al., 1986; Opp et al., 1989). CRF also inhibits the excess non-REM sleep induced by interleukin-1 (Opp et al., 1989) and can delay the rebound sleep that occurs after prolonged REM deprivation (Marrosu et al., 1990). The CRF receptor 1 antagonist R121919 attenuates stress-elicited sleep disturbances in rats, particularly in a high innate anxiety strain (Lancel et al., 2002).

Activation of the hypocretinergic system by CRF during stress supports the notion that the hypocretins may be in a key position to integrate and transmit the stress signals to other brain and peripheral regions. Hypocretin neurons send dense projections to the noradrenergic locus ceruleus and the serotoninergic dorsal raphe, regions implicated in the regulation of behavioral state (Peyron et al., 1998). Hypocretins increase firing of locus ceruleus noradrenergic neurons in vitro (Hagan et al., 1999) and in vivo (Horvath et al., 1999b; Bourgin et al., 2000), and the noradrenergic system is part of the stress circuitry. The robust projection of hypocretinergic fiber system in the spinal cord suggest that the hypocretins may be involved in the modulation of sensory input and autonomic tone (van den Pol, 1999; Date et al., 2000; Hervieu et al., 2001).

Activation of the hypocretinergic system by stress likely acts on different targets. First, hypocretin may activate the HPA axis via the increased release of CRF in the median eminence. Indeed, hypocretin-containing neurons send dense projection to the PVN and CRF neurons located in this nucleus express abundantly the hypocretin type-2 receptor gene, suggesting that hypocretin could modulate the activity of CRF-expressing neurons (Marcus et al., 2001). Footshock-sensitive neurons in lateral hypothalamus have been described that project to the PVN (Li and Sawchenko, 1998). Furthermore, hypocretin-1 induces c-Fos expression in the PVN (Ida et al., 2000a) and dose dependently stimulates ACTH and corticosterone release (Hagan et al., 1999; Ida et al., 2000a; Jaszberenyi et al., 2000; Kuru et al., 2000; Samson et al., 2002). Pretreatment with $\alpha$-helical CRF, a CRF antagonist, blocks the corticosterone elevation induced by hcrt (Ida et al., 2000b; Jaszberenyi et al., 2000; Samson et al., 2002). Hypocretindeficient narcoleptic patients have a lower basal ACTH release, suggesting reduced CRF tonus, although cortisol secretion did not differ from that of controls (Kok et al., 2002). Whether hcrt regulates CRF in a feedback loop remains to be established.

In addition to the effect of the hypocretins at the hypothalamic level, neuroanatomical studies support a direct effect on the anterior pituitary because both hypocretinergic receptors have been detected in this region (Blanco et al., 2001, 2003). The hypocretins have an inhibitory effect on CRF-stimulated ACTH release from anterior pituitary cells in vitro (Samson and Taylor, 2001). Hypocretin receptors are also expressed in the adrenal gland: hcrt-r1 expression was reported in the cortex and hort-r2 in the medulla (i. e., epinephrine- and norepinephrineexpressing cells) (Lopez et al., 1999). Adrenalectomy induces a marked decrease of the pre-prohypocretin mRNA expression lev- 


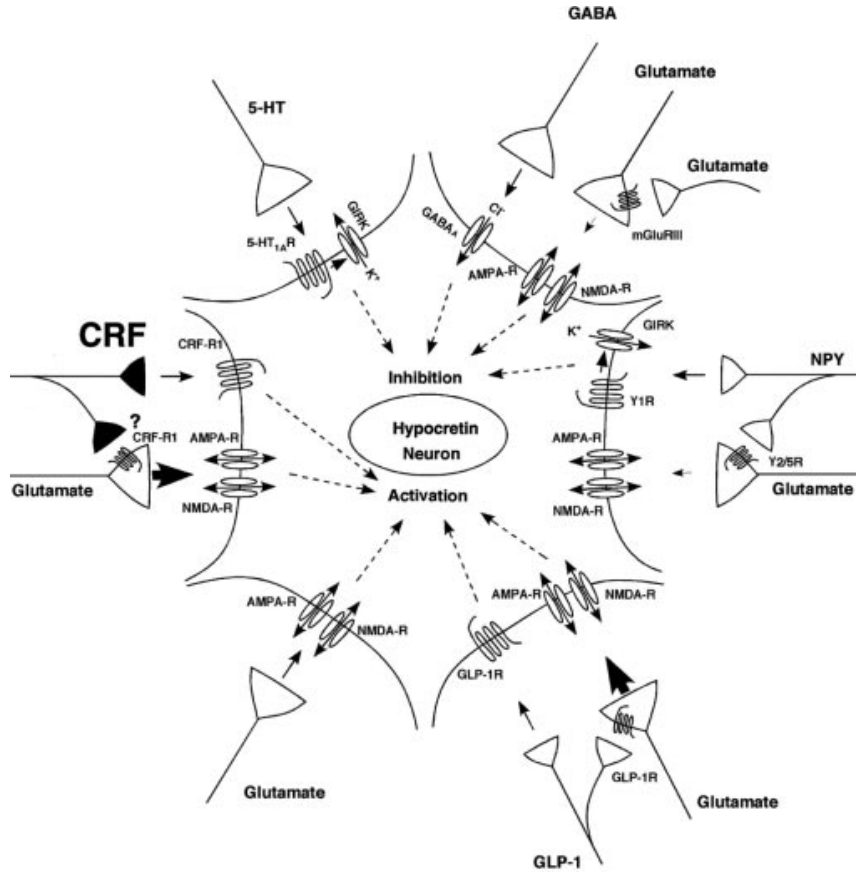

Figure 8. Schematic illustrating electrophysiologically demonstrated inputs to hypocretin neurons. The present study demonstrates that CRF can depolarize a subset of these neurons through the CRF-R1. Other inputs are not illustrated because the receptor mediating the response has yet to be determined, including noradrenergic and cholinergic inputs and other factors such as leptin, glucose, and ghrelin.

els, which were restored after peripheral glucocorticoid treatment (Stricker-Krongrad and Beck, 2002).

The significance of the current results at the systems level is schematically summarized in Figure 8. Previous electrophysiological studies have demonstrated that hypocretin cells can be depolarized by glutamate through both AMPA and NMDA receptors (Li et al., 2002; Yamanaka et al., 2003a) and by glucagonlike peptide 1 (GLP-1) (Acuna-Goycolea and van den Pol, 2004). The excitatory glutamatergic input appears to be under presynaptic control by group III metabotropic glutamate receptors (Acuna-Goycolea et al., 2004), neuropeptide Y2/Y5 receptors (Fu et al., 2004), and GLP-1 receptors (Acuna-Goycolea and van den Pol, 2004). Conversely, these neurons can be hyperpolarized by GABA acting on $\mathrm{GABA}_{\mathrm{A}}$ receptors (Li et al., 2002; Eggermann et al., 2003; Yamanaka et al., 2003a), by serotonin through 5- $\mathrm{HT}_{1 \mathrm{~A}}$ receptors (Muraki et al., 2004) and by neuropeptide Y through Y1 receptors (Fu et al., 2004). Other studies indicate that norepinephrine inhibits (Li et al., 2002; Yamanaka et al., 2003a) and cholinergic activation depolarizes (Yamanaka et al., 2003a) these neurons, but the specific receptors mediating these responses are yet to be identified. In addition, glucose and leptin inhibit hypocretin cells, and ghrelin excites a subset of these neurons (Yamanaka et al., 2003b). The present study demonstrates that CRF acting on the CRF-R1 can also depolarize a subset of hort neurons, although it is unclear whether part of this effect is attributable to presynaptic modulation of other excitatory input.

In summary, our results provide evidence of a direct neuroanatomical and physiological link between CRF and hypocretin systems and suggest that hypocretins activate brain circuits that modulate arousal associated with the footshocks and restraint stress response paradigms.

\section{References}

Acuna-Goycolea C, van den Pol A (2004) Glucagon-like peptide 1 excites hypocretin/orexin neurons by direct and indirect mechanisms: implications for viscera-mediated arousal. J Neurosci 24:8141-8152.

Acuna-Goycolea C, Li Y, van Den Pol AN (2004) Group III metabotropic glutamate receptors maintain tonic inhibition of excitatory synaptic input to hypocretin/orexin neurons. J Neurosci 24:3013-3022.

Alam MN, Gong H, Alam T, Jaganath R, McGinty D, Szymusiak R (2002) Sleep-waking discharge patterns of neurons recorded in the rat perifornical lateral hypothalamic area. J Physiol (Lond) 538:619-631.

Blanco M, Lopez M, GarcIa-Caballero T, Gallego R, Vazquez-Boquete A, Morel G, SenarIs R, Casanueva F, Dieguez C, Beiras A (2001) Cellular localization of orexin receptors in human pituitary. J Clin Endocrinol Metab 86:1616-1619.

Blanco M, Gallego R, Garcia-Caballero T, Dieguez C, Beiras A (2003) Cellular localization of orexins in human anterior pituitary. Histochem Cell Biol 120:259-264.

Bourgin P, Huitron-Resendiz S, Spier AD, Fabre V, Morte B, Criado JR, Sutcliffe JG, Henriksen SJ, de Lecea L (2000) Hypocretin-1 modulates rapid eye movement sleep through activation of locus ceruleus neurons. J Neurosci 20:7760-7765.

Chan RK, Brown ER, Ericsson A, Kovacs KJ, Sawchenko PE (1993) A comparison of two immediate-early genes, c-fos and NGFI-B, as markers for functional activation in stress-related neuroendocrine circuitry. J Neurosci 13:5126-5138.

Chemelli RM, Willie JT, Sinton CM, Elmquist JK, Scammell T, Lee C, Richardson JA, Williams SC, Xiong Y, Kisanuki Y, Fitch TE, Nakazato M, Hammer RE, Saper CB, Yanagisawa M (1999) Narcolepsy in orexin knockout mice: molecular genetics of sleep regulation. Cell 98:437-451.

Chen Y, Brunson KL, Muller MB, Cariaga W, Baram TZ (2000) Immunocytochemical distribution of corticotropin-releasing hormone receptor type-1 (CRF(1))-like immunoreactivity in the mouse brain: light microscopy analysis using an antibody directed against the C-terminus. J Comp Neurol 420:305-323.

Cluderay JE, Harrison DC, Hervieu GJ (2002) Protein distribution of the orexin-2 receptor in the rat central nervous system. Regul Pept 104:131-144.

Cowley MA, Smith RG, Diano S, Tschop M, Pronchuk N, Grove KL, Strasburger CJ, Bidlingmaier M, Esterman M, Heiman ML, Garcia-Segura LM, Nillni EA, Mendez P, Low MJ, Sotonyi P, Friedman JM, Liu H, Pinto S, Colmers WF, Cone RD, Horvath TL (2003) The distribution and mechanism of action of ghrelin in the CNS demonstrates a novel hypothalamic circuit regulating energy homeostasis. Neuron 37:649-661.

Date Y, Mondal MS, Matsukura S, Nakazato M (2000) Distribution of orexin-A and orexin-B (hypocretins) in the rat spinal cord. Neurosci Lett 288:87-90.

de Lecea L, Kilduff TS, Peyron C, Gao X, Foye PE, Danielson PE, Fukuhara C, Battenberg EL, Gautvik VT, Bartlett FS, 2nd, Frankel WN, van den Pol AN, Bloom FE, Gautvik KM, Sutcliffe JG (1998) The hypocretins: hypothalamus-specific peptides with neuroexcitatory activity. Proc Natl Acad Sci USA 95:322-327.

Diano S, Horvath B, Urbanski HF, Sotonyi P, Horvath TL (2003) Fasting activates the nonhuman primate hypocretin (orexin) system and its postsynaptic targets. Endocrinology 144:3774-3778.

Duxon MS, Stretton J, Starr K, Jones DN, Holland V, Riley G, Jerman J, Brough S, Smart D, Johns A, Chan W, Porter RA, Upton N (2001) Evidence that orexin-A-evoked grooming in the rat is mediated by orexin-1 (OX1) receptors, with downstream 5-HT2C receptor involvement. Psychopharmacology (Berl) 153:203-209.

Eggermann E, Bayer L, Serafin M, Saint-Mleux B, Bernheim L, Machard D, Jones BE, Muhlethaler M (2003) The wake-promoting hypocretinorexin neurons are in an intrinsic state of membrane depolarization. J Neurosci 23:1557-1562.

Ehlers CL, Reed TK, Henriksen SJ (1986) Effects of corticotropin-releasing factor and growth hormone-releasing factor on sleep and activity in rats. Neuroendocrinology 42:467-474.

Espana RA, Valentino RJ, Berridge CW (2003) Fos immunoreactivity in hypocretin-synthesizing and hypocretin-1 receptor-expressing neurons: effects of diurnal and nocturnal spontaneous waking, stress and hypocretin-1 administration. Neuroscience 121:201-217. 
Fadel J, Bubser M, Deutch AY (2002) Differential activation of orexin neurons by antipsychotic drugs associated with weight gain. J Neurosci 22:6742-6746.

Franklin KBJ, Paxinos G (1997) The mouse brain in stereotaxic coordinates. San Diego: Academic.

Fu LY, Acuna-Goycolea C, van den Pol AN (2004) Neuropeptide Y inhibits hypocretin/orexin neurons by multiple presynaptic and postsynaptic mechanisms: tonic depression of the hypothalamic arousal system. J Neurosci 24:8741-8751.

Hagan JJ, Leslie RA, Patel S, Evans ML, Wattam TA, Holmes S, Benham CD, Taylor SG, Routledge C, Hemmati P, Munton RP, Ashmeade TE, Shah AS, Hatcher JP, Hatcher PD, Jones DN, Smith MI, Piper DC, Hunter AJ, Porter RA, Upton N (1999) Orexin A activates locus coeruleus cell firing and increases arousal in the rat. Proc Natl Acad Sci USA 96:10911-10916.

Hara J, Beuckmann CT, Nambu T, Willie JT, Chemelli RM, Sinton CM, Sugiyama F, Yagami K, Goto K, Yanagisawa M, Sakurai T (2001) Genetic ablation of orexin neurons in mice results in narcolepsy, hypophagia, and obesity. Neuron 30:345-354.

Hervieu GJ, Cluderay JE, Harrison DC, Roberts JC, Leslie RA (2001) Gene expression and protein distribution of the orexin-1 receptor in the rat brain and spinal cord. Neuroscience 103:777-797.

Horvath TL, Diano S, van den Pol AN (1999a) Synaptic interaction between hypocretin (orexin) and neuropeptide Y cells in the rodent and primate hypothalamus: a novel circuit implicated in metabolic and endocrine regulations. J Neurosci 19:1072-1087.

Horvath TL, Peyron C, Diano S, Ivanov A, Aston-Jones G, Kilduff TS, van den Pol AN (1999b) Hypocretin (orexin) activation and synaptic innervation of the locus coeruleus noradrenergic system. J Comp Neurol 415:145-159.

Ida T, Nakahara K, Murakami T, Hanada R, Nakazato M, Murakami N (2000a) Possible involvement of orexin in the stress reaction in rats. Biochem Biophys Res Commun 270:318-323.

Ida T, Nakahara K, Kuroiwa T, Fukui K, Nakazato M, Murakami T, Murakami $\mathrm{N}$ (2000b) Both corticotropin releasing factor and neuropeptide $\mathrm{Y}$ are involved in the effect of orexin (hypocretin) on the food intake in rats. Neurosci Lett 293:119-122.

Jaszberenyi M, Bujdoso E, Pataki I, Telegdy G (2000) Effects of orexins on the hypothalamic-pituitary-adrenal system. J Neuroendocrinol 12:1174-1178.

Jones DN, Gartlon J, Parker F, Taylor SG, Routledge C, Hemmati P, Munton RP, Ashmeade TE, Hatcher JP, Johns A, Porter RA, Hagan JJ, Hunter AJ, Upton N (2001) Effects of centrally administered orexin-B and orexin-A: a role for orexin-1 receptors in orexin-B-induced hyperactivity. Psychopharmacology (Berl) 153:210-218.

Kayaba Y, Nakamura A, Kasuya Y, Ohuchi T, Yanagisawa M, Komuro I, Fukuda Y, Kuwaki T (2003) Attenuated defense response and low basal blood pressure in orexin knockout mice. Am J Physiol Regul Integr Comp Physiol 285:R581-R593.

Kok SW, Roelfsema F, Overeem S, Lammers GJ, Strijers RL, Frolich M, Meinders AE, Pijl H (2002) Dynamics of the pituitary-adrenal ensemble in hypocretin-deficient narcoleptic humans: blunted basal adrenocorticotropin release and evidence for normal time-keeping by the master pacemaker. J Clin Endocrinol Metab 87:5085-5091.

Kuru M, Ueta Y, Serino R, Nakazato M, Yamamoto Y, Shibuya I, Yamashita H (2000) Centrally administered orexin/hypocretin activates HPA axis in rats. NeuroReport 11:1977-1980.

Lancel M, Muller-Preuss P, Wigger A, Landgraf R, Holsboer F (2002) The CRH1 receptor antagonist R121919 attenuates stress-elicited sleep disturbances in rats, particularly in those with high innate anxiety. J Psychiatr Res 36:197-208.

Li HY, Sawchenko PE (1998) Hypothalamic effector neurons and extended circuitries activated in "neurogenic" stress: a comparison of footshock effects exerted acutely, chronically, and in animals with controlled glucocorticoid levels. J Comp Neurol 393:244-266.

Li Y, Gao XB, Sakurai T, van den Pol AN (2002) Hypocretin/orexin excites hypocretin neurons via a local glutamate neuron-A potential mechanism for orchestrating the hypothalamic arousal system. Neuron 36:1169-1181.

Lin L, Faraco J, Li R, Kadotani H, Rogers W, Lin X, Qiu X, de Jong PJ,
Nishino S, Mignot E (1999) The sleep disorder canine narcolepsy is caused by a mutation in the hypocretin (orexin) receptor 2 gene. Cell 98:365-376.

Lopez M, Senaris R, Gallego R, Garcia-Caballero T, Lago F, Seoane L, Casanueva F, Dieguez C (1999) Orexin receptors are expressed in the adrenal medulla of the rat. Endocrinology 140:5991-5994.

Makino S, Hashimoto K, Gold PW (2002) Multiple feedback mechanisms activating corticotropin-releasing hormone system in the brain during stress. Pharmacol Biochem Behav 73:147-158.

Marcus JN, Aschkenasi CJ, Lee CE, Chemelli RM, Saper CB, Yanagisawa M, Elmquist JK (2001) Differential expression of orexin receptors 1 and 2 in the rat brain. J Comp Neurol 435:6-25.

Marrosu F, Gessa GL, Giagheddu M, Fratta W (1990) Corticotropinreleasing factor (CRF) increases paradoxical sleep (PS) rebound in PSdeprived rats. Brain Res 515:315-318.

Merchenthaler I, Vigh S, Petrusz P, Schally AV (1982) Immunocytochemical localization of corticotropin-releasing factor (CRF) in the rat brain. Am J Anat 165:385-396.

Muraki Y, Yamanaka A, Tsujino N, Kilduff TS, Goto K, Sakurai T (2004) Serotonergic regulation of the orexin/hypocretin neurons through the 5-HT1A receptor. J Neurosci 24:7159-7166.

Nakamura T, Uramura K, Nambu T, Yada T, Goto K, Yanagisawa M, Sakurai T (2000) Orexin-induced hyperlocomotion and stereotypy are mediated by the dopaminergic system. Brain Res 873:181-187.

Opp M, Obal Jr F, Krueger JM (1989) Corticotropin-releasing factor attenuates interleukin 1-induced sleep and fever in rabbits. Am J Physiol 257:R528-R535.

Owens MJ, Nemeroff CB (1991) Physiology and pharmacology of corticotropin-releasing factor. Pharmacol Rev 43:425-473.

Peyron C, Tighe DK, van den Pol AN, de Lecea L, Heller HC, Sutcliffe JG, Kilduff TS (1998) Neurons containing hypocretin (orexin) project to multiple neuronal systems. J Neurosci 18:9996-10015.

Reyes TM, Walker JR, DeCino C, Hogenesch JB, Sawchenko PE (2003) Categorically distinct acute stressors elicit dissimilar transcriptional profiles in the paraventricular nucleus of the hypothalamus. J Neurosci 23:5607-5616.

Sakurai T, Amemiya A, Ishii M, Matsuzaki I, Chemelli RM, Tanaka H, Williams SC, Richardson JA, Kozlowski GP, Wilson S, Arch JR, Buckingham RE, Haynes AC, Carr SA, Annan RS, McNulty DE, Liu WS Terrett JA, Elshourbagy NA, Bergsma DJ, Yanagisawa M (1998) Orexins and orexin receptors: a family of hypothalamic neuropeptides and $\mathrm{G}$ protein-coupled receptors that regulate feeding behavior. Cell 92:573-585.

Samson WK, Taylor MM (2001) Hypocretin/orexin suppresses corticotroph responsiveness in vitro. Am J Physiol Regul Integr Comp Physiol 281:R1140-R1145.

Samson WK, Gosnell B, Chang JK, Resch ZT, Murphy TC (1999) Cardiovascular regulatory actions of the hypocretins in brain. Brain Res 831:248-253

Samson WK, Taylor MM, Follwell M, Ferguson AV (2002) Orexin actions in hypothalamic paraventricular nucleus: physiological consequences and cellular correlates. Regul Pept 104:97-103.

Sauvage M, Steckler T (2001) Detection of corticotropin-releasing hormone receptor 1 immunoreactivity in cholinergic, dopaminergic and noradrenergic neurons of the murine basal forebrain and brainstem nuclei-potential implication for arousal and attention. Neuroscience 104:643-652.

Shirasaka T, Nakazato M, Matsukura S, Takasaki M, Kannan H (1999) Sympathetic and cardiovascular actions of orexins in conscious rats. Am J Physiol 277:R1780-R1785.

Smith GW, Aubry JM, Dellu F, Contarino A, Bilezikjian LM, Gold LH, Chen R, Marchuk Y, Hauser C, Bentley CA, Sawchenko PE, Koob GF, Vale W, Lee KF (1998) Corticotropin releasing factor receptor 1-deficient mice display decreased anxiety, impaired stress response, and aberrant neuroendocrine development. Neuron 20:1093-1102.

Stricker-Krongrad A, Beck B (2002) Modulation of hypothalamic hypocretin/orexin mRNA expression by glucocorticoids. Biochem Biophys Res Commun 296:129-133.

Sutcliffe JG, de Lecea L (2002) The hypocretins: setting the arousal threshold. Nat Rev Neurosci 3:339-349.

Takahashi N, Okumura T, Yamada H, Kohgo Y (1999) Stimulation of gas- 
tric acid secretion by centrally administered orexin-A in conscious rats. Biochem Biophys Res Commun 254:623-627.

Timpl P, Spanagel R, Sillaber I, Kresse A, Reul JM, Stalla GK, Blanquet V, Steckler T, Holsboer F, Wurst W (1998) Impaired stress response and reduced anxiety in mice lacking a functional corticotropin-releasing hormone receptor 1. Nat Genet 19:162-166.

van den Pol AN (1999) Hypothalamic hypocretin (orexin): robust innervation of the spinal cord. J Neurosci 19:3171-3182.

Willie JT, Chemelli RM, Sinton CM, Tokita S, Williams SC, Kisanuki YY, Marcus JN, Lee C, Elmquist JK, Kohlmeier KA, Leonard CS, Richardson JA, Hammer RE, Yanagisawa M (2003) Distinct narcolepsy syndromes in Orexin receptor-2 and Orexin null mice: molecular genetic dissection of Non-REM and REM sleep regulatory processes. Neuron 38:715-730.

Yamanaka A, Muraki Y, Tsujino N, Goto K, Sakurai T (2003a) Regulation of orexin neurons by the monoaminergic and cholinergic systems. Biochem Biophys Res Commun 303:120-129.

Yamanaka A, Beuckmann CT, Willie JT, Hara J, Tsujino N, Mieda M, Tominaga M, Yagami K, Sugiyama F, Goto K, Yanagisawa M, Sakurai T (2003b) Hypothalamic orexin neurons regulate arousal according to energy balance in mice. Neuron 38:701-713.

Yoshimichi G, Yoshimatsu H, Masaki T, Sakata T (2001) Orexin-A regulates body temperature in coordination with arousal status. Exp Biol Med (Maywood) 226:468-476. 